\begin{tabular}{c}
\hline \hline Juntendo \\
Research Profiles \\
\hline \hline Juntendo Medical Journal \\
2015. 61 (5), 526-527
\end{tabular}

\title{
Department of Rehabilitation Medicine
}

\section{Principal Investigator: Masanori Nagaoka (Professor)}

The research in our department has been in various fields of rehabilitation medicine since the establishment of our department in 2003.

1. Research on pathophysiological mechanisms of impairment

2. Development of novel interventions for various impairments

3. Role of medical model and disabled model

4. Introduction of concept of ICF in the milieu of an acute hospital

5. Research of different disabilities, namely, physical disability, disabled by internal medicine, mentally disabled and disabled in sensory organs

6. Study of QOL in rehabilitation

7. Construction of network in rehabilitation

8. Research on rehabilitation engineering

Parkinson's disease is the main target of our research. Rigidity as one of its cardinal symptoms is a main topic. Kakuda N and Nagaoka M are studying physiologically the mechanisms of rigidity and the role of the gamma system by microneurography.

Nagaoka $M$ is attempting to develop effective therapeutic exercise for patients with Parkinson's disease.

As a tool to measure QOL, Nagaoka M joined the project for the development of a Japanese version of PDQ-39 for patients with Parkinson's disease. Terakado A reported the effect of exercise for the elderly and measured it using SF-36.

As for pathophysiological study, Lin SN published a paper showing the effect of physiotherapy on dropped head syndromes. In this paper, she showed the common findings of dropped head syndromes electromyographically ${ }^{11}$.

Kurosu A, Associate Professor at Juntendo Nerima Hospital, published a paper on a series of patients with lesions in the internal nucleus of $\mathrm{Cajal}^{2)}$. In this paper, he attempted to elucidate the mechanism of recovery in neurological disorder related to disequilibrium.

Spasticity is a well-known symptom in stroke and paraplegic patients. As a novel treatment of spasticity, Lin SN et al. published a paper in which the effect of vibratory stimuli on spasticity was shown kinesiologically and electro-physiologically ${ }^{3)}$.

As research related to rehabilitation engineering, Nagaoka M collaborated with two engineering departments, Tokyo Engineering University and Waseda University. Associate Professor Hideyuki Tsukagoshi from Tokyo Engineering University developed a device for vibratory stimulation using hydraulic pressure, which is applicable in MRI. Masatoshi Seki and Yuya Matsumoto from Waseda University published a paper on an assistive device for patients with essential tremor ${ }^{4)}{ }^{5)}$. As for amputees, Terakado A reported the usefulness of Immediate Postoperative Prosthesis Using Silicone Socket (IPOPSS).

In an acute hospital such as Juntendo University Hospital, rehabilitation for cancer patients is very demanding, particularly from the viewpoint of prevention of pathological fracture. Hayashi Y, Kitahara E, Izawa $\mathrm{N}$ and Hatori $\mathrm{K}$, in collaboration with Takagi T, Associate Professor of Orthopedic Surgery, reported the important role of SRE conference.

Publications:

1) Lin HN, Nagaoka M, Hayashi Y, Yonezawa I: Pathophysiological analysis of dropped head syndrome caused by various diagnoses - based on surface EMG findings and responses to physiotherapy. Rinsho Shinkeigaku, 2013; 53: 430-438. Japanese. PubMed PMID: 23782820.

2) Kurosu A, Hayashi Y, Wada K, Nagaoka M: Gait balance disorder by thalamic infarction with the disorder of interstitial nucleus of Cajal. Clin Med Insights Case Rep. 2011; 4: 7-11.

3) Lin HN, Nagaoka M, Hayashi Y, Hatori K: Effect of vibration stimulation on dysbasia of spastic paraplegia in neuromyelitis optica: a possible example of neuronal plasticity. BMJ Case Rep, 2012; pii: bcr2012006793.

4) Seki M, Matsumoto Y, Ando T, Kobayashi Y, Iijima H, Nagaoka M, Fujie MG: Filtering essential tremor noise on surface EMG based on squared sine wave approximation. Conf Proc IEEE Eng Med Biol Soc, 2011; 2011: 7487-7491.

5) Matsumoto Y, Seki M, Ando T, Kobayashi Y, Iijima H, Nagaoka M, Fujie MG: Analysis of EMG signals of patients with essential tremor focusing on the change of tremor frequency. Conf Proc IEEE Eng Med Biol Soc, 
2012; 2012: 2244-2250.

\section{1) Akito Hayashi (Professor)}

We have investigated the mechanism of dropped head syndrome with Parkinson's disease and other types of parkinsonism ${ }^{122)}$.

My interests include rehabilitation for Parkinson's disease and I've been a member of a working group of guidelines for treatments of Parkinson's disease in Japan since $2009^{3)-5 \text { ) }}$.

Music therapy of Parkinson's disease is one of the main focuses of studies for rehabilitation. I have investigated a new method of evaluating gait using a portable gait rhythmogram. I am also a member of the dystonia working group in Japan and my special interest is botulinum toxin treatment.

Publications:

1) Oyama G, Hayashi A, Mizuno Y, Hattori N: Mechanism and treatment of dropped head syndrome associated with parkinsonism. Parkinsonism Relat Disord, 2009; 15: 181-186.

2) Funabe S, Tanaka R, Hayashi A, Yamashiro K, Shimura $\mathrm{H}$, Hattori N: Reversible dropped head syndrome after hemispheric striatal infarction. J Stroke Cerebrovasc Dis, 2014; 23: 785-787.

3) 林 明人: パーキンソン病診療 Q\&A パーキンソン病 のリハビリテーション. Fronti Parkinson Dis, 2009; 2: 236-238.

4) 林 明人: パーキンソン病のリハビリテーション治療. 最新医, 2010; 65: 892-896.

5) 林 明人: パーキンソン病のリハビリテーション．綜合 臨, 2010; 59: 2448-2453.

\section{2) Kozo Hatori (Associate Professor)}

Our main projects are on exercise therapies and swallowing disorders, with particular emphasis on neurodegenerative disorders. We have just been working for a few years, and have mainly been developing clinical investigations, which are underway to build up research protocols of exercise therapy and to analyze the swallowing disorders in parkinsonism by radiological methods. These projects continue to evolve, and we will soon report the recent findings ${ }^{1-5)}$.

Publications:

1）篠原幸人, 伊藤裕乃, 児矢野 繁, 澤山泰典, 萩原万里 子，羽鳥浩三，松本真一，OASIS研究グループ: 健康関 連 Quality of Lifeに与える脳卒中後広義のめまいの影響 と ibudilastの効果—Outcome Assessment using SF-36 v2 In Stroke patients (OASIS) 研究より一. 神経治療, 2009; 26: 197-208.

2) 羽鳥浩三, 籠橋麻紀, 鈴木康司, 涉谷康則, 林 明人, 長 岡正範: 両側喉頭不全麻痺を認めた咽頭・頚部・上腕型 Guillain-Barré 症候群 の一例. 運動障害, 2009; 19: 39-45.

3) Yagihashi T, Hatori K, Ishii K, Torii C, Momoshima S, Takahashi T, Kosaki K: Juvenile muscular atrophy of a unilateral upper extremity (Hirayama disease) in a patient with CHARGE syndrome. Mol Syndromol, 2010; 1: 91-94.

4) 林 欣霓, 長岡正範, 林 康子, 羽鳥浩三, 寺門厚彦, 高 梨雅史, 牧 雄介: 痤性対麻疩の歩行障害に振動刺激が 有効であったNeuromyelitis Opticaの一例．運動障害， 2011; 21: 15-21.

5) 羽鳥浩三, 籠橋麻紀: 脱力. 内科, 2009; 103: 1100-1105.

\section{3) Akihiro Kurosu (Associate Professor)}

Our hospital is an acute-care hospital rooted in the local area, and mainly treats orthopedic diseases and apoplexy. In particular, we focus on the treatment of stroke, and one of our research projects is on gait balance disorder due to dysfunction of the interstitial nucleus of Cajal ${ }^{11}$.

Publications:

1) Kurosu A, Hayashi Y, Wada K, Nagaoka M: Gait balance disorder by thalamic infarction with the disorder of interstitial nucleus of Cajal. Clin Med Insights Case Rep, 2011; 4: 7-11. 